\title{
Topp og bunn
}

\author{
Hvordan bør begrepene «trough level» og «peak level» oversettes?
}

Uttrykket «trough level» har dukket opp som den nye vinen i gastroenterologien. Dette kan sågar spare oss for flere millioner kroner i året! I de sammenhengene jeg har sett det anvendt, kan mye tyde på at uttrykket delvis brukes synonymt til serumkonsentrasjonen av et medikament uavhengig av tidssammenhengen mellom medikamentadministrasjon og prøvetaking. Et litt vanskelig engelsk uttrykk kan tenkes å miste sin presisjon der engelsk er språk nummer 2. Spørsmålet er hva dette skal kalles på norsk? Generelt brukes både serumspeil og serumnivå og gir en oversettelse av «trough level», basert på etterstavelsen, til hhv. bunnspeil og bunnivå. Hva foretrekkes på norsk; eller er de likeverdige?

Kim V. Ånonsen

kanonsen1@gmail.com

Oslo universitetssykehus

Kim V. Ånonsen (f.1972) er assistentlege ved Gastromedisinsk avdeling, Medisinsk klinikk, Oslo universitetssykehus.

Mottatt 14.9. 2012 og godkjent 2.10. 2012. Medisinsk redaktør Raida Ødegaard.

\section{Redaksjonen svarer:}

Det er ikke helt opplagt hvilken betegnelse som bør anvendes på norsk, og innlegget har ført til diskusjoner i redaksjonen.

Orddanning etter mønster av serumspeil bør nok ikke velges ettersom betegnelsen serumspeil er forlatt (1) - selv om vi på tysk finner oversettelsen messpegel. På spansk heter det consentracion plasmatica minima, og varianter som «minste serumkonsentrasjon» eller «laveste serumkonsentrasjon»

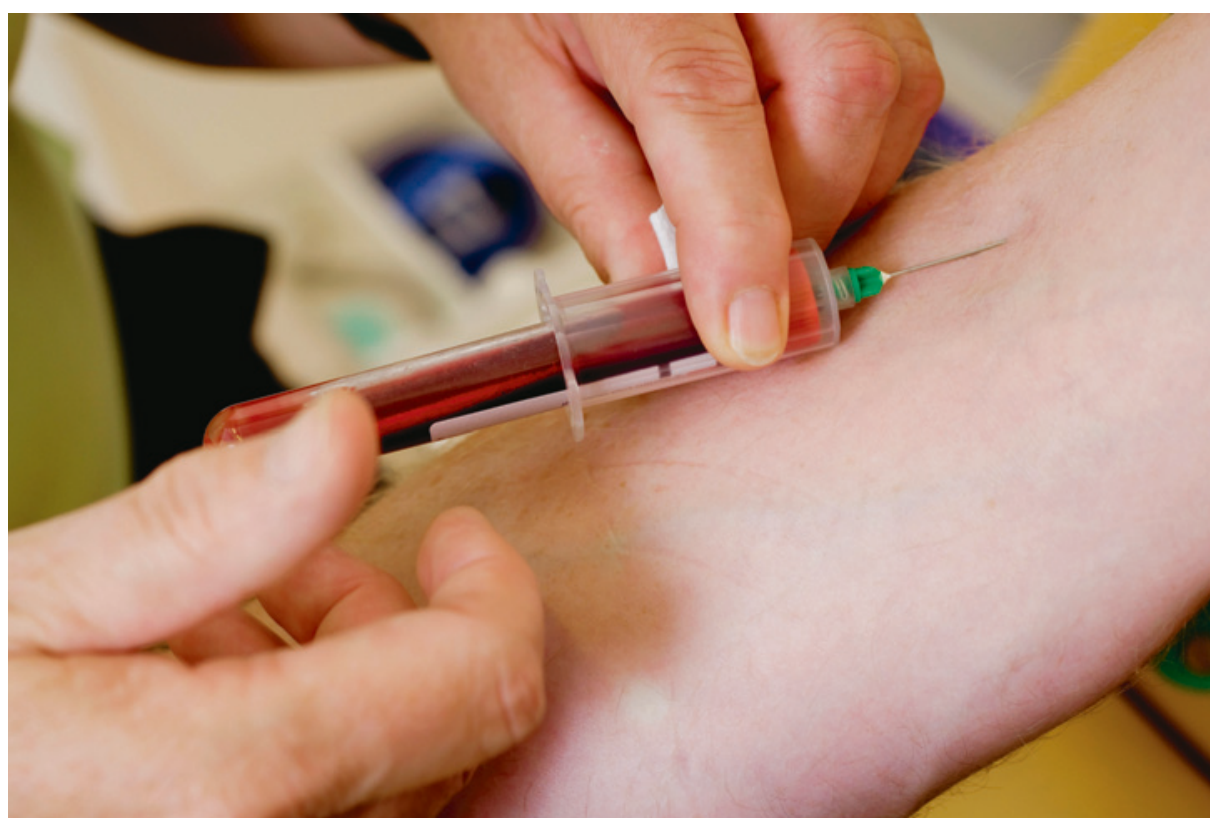

Illustrasjonsfoto Science Photo Library/NTB scanpix

kan fungere også på norsk. Et alternativ kunne være «bunnkonsentrasjon», mens «bunnivå» kan gi feilaktige assosiasjoner, som om det skulle være noe lite ønskelig, jf. bunnotering, bunnresultat, bunnlag, etc. Ulempen med «minste serumkonsentrasjon» eller «laveste serumkonsentrasjon» er lengden.

Når motsatsen til «trough level» er «peak level», tror vi at topp og bunn kan klinge ganske godt på norsk. De ligger også rimelig tett opp til det engelske: topp- og bunnkonsentrasjon. Dermed er et par forutsetninger for å lykkes med avløserord oppfylt.

$\mathrm{Vi}$ er derfor kommet frem til toppkonsentrasjon og bunnkonsentrasjon som foretrukne betegnelser, og de vil bli brukt i Tidsskriftet.

\section{Raida Ødegaard}

raida.oedegaard@legeforeningen.no Erlend Hem

Tidsskriftet

Raida Ødegaard (f. 1946) er filolog og manuskriptredaktør i Tidsskriftet.

Erlend Hem (f. 1970) er dr.med. og assisterende redaktør i Tidsskriftet.

\footnotetext{
Litteratur

1. Ødegaard R, Hem E. Serumspeil - en reminisens. Tidsskr Nor Lægeforen 2007; 127: 1541.
} 